\title{
Soil Metals and Ectomycorrhizal Fungi Associated with American Chestnut Hybrids as Reclamation Trees on Formerly Coal Mined Land
}

\author{
J. M. Bauman, ${ }^{1}$ J. Adamson, ${ }^{1}$ R. Brisbin, ${ }^{2}$ E. T. Cline, ${ }^{2}$ and C. H. Keiffer ${ }^{3}$ \\ ${ }^{1}$ Huxley College of the Environment, Western Washington University, Poulsbo, WA 98225, USA \\ ${ }^{2}$ Environmental Sciences, University of Washington, Tacoma, WA 98402, USA \\ ${ }^{3}$ Department of Biology, Miami University, 114 Levey Hall, Middletown, OH 45042, USA \\ Correspondence should be addressed to J. M. Bauman; jenise.bauman@wwu.edu
}

Received 28 July 2017; Accepted 17 October 2017; Published 19 December 2017

Academic Editor: Maria Serrano

Copyright (C) 2017 J. M. Bauman et al. This is an open access article distributed under the Creative Commons Attribution License, which permits unrestricted use, distribution, and reproduction in any medium, provided the original work is properly cited.

\begin{abstract}
Hybrid chestnut (Castanea dentata $\times$ C. mollissima) has the potential to provide a valuable agroforestry crop on formerly coal mined landscapes. However, the soil interactions of mycorrhizal fungi and buried metals associated with mining are not known. This study examined soil, plant tissue, and ectomycorrhizal (ECM) root colonization on eight-year-old hybrid $\left(\mathrm{BC}_{1} \mathrm{~F}_{3}\right.$ and $\left.\mathrm{BC}_{2} \mathrm{~F}_{3}\right)$ and American chestnuts on a reclaimed coal mine in Ohio, USA. Chestnut trees were measured and ECM colonization on roots was quantified. Leaves, flowers, and soil were analyzed for heavy metals. Differences were not detected among tree types regarding metal accumulation in plant tissue or ECM colonization. $\mathrm{BC}_{2} \mathrm{~F}_{3}$ hybrids had greater survival and less cankers than American chestnuts $(P=0.006$ and $<0.0001)$. Taller trees were associated with greater ECM root colonization and correlated with an increase in $\mathrm{Al}$ uptake $(P=0.02$ and 0.01$)$. When comparing tissue, manganese and aluminum were in higher concentrations in leaves than flowers, where copper and selenium were significantly higher in floral tissue $(P<0.05)$. All trees were flowering at this time meriting further examination in nut tissue. Block effects for selenium and zinc indicate the variability in reclaimed soils requiring further monitoring for possible elemental transfer to nut and wood tissue.
\end{abstract}

\section{Introduction}

The American chestnut (Castanea dentata Marsh. Borkh.) has been a historic North American multipurpose tree valued for its building versatility, valuable proteins, and rich tannins [1]. American chestnut occupied, on average, twenty-five percent of the eastern forest and in certain forest stands comprised more than fifty percent [2]. On productive sites, American chestnut added up to one inch in diameter annually with an estimated 500 board feet produced per acre per year $[3,4]$. Also, this species was a plentiful seed resource for humans, livestock, and wildlife in the Appalachian region [5]. Historically, the nut was a plentiful protein source used by the Native Americans and by the 1800s was an important crop for livestock, human consumption, and income and trade for the residents of southern Appalachian [6]. With the expansion of the transportation system in the mid to late 1800s, chestnut became an important agricultural commodity providing timber and food. Unfortunately, a novel pathogen from Asia identified as chestnut blight (Cryphonectria parasitica) resulted in widespread mortality of the American chestnut throughout the eastern deciduous forests of North America [7].

Chestnut's cultural significance, ecologic importance, and economic value have motivated breeding strategies to restore this species to eastern forests [8]. Early breeding programs hybridized American chestnuts with blight-resistant Asian species (C. mollissima and C. crenata) to produce trees resistant to blight. However, blight-resistant progenies did not display the growth form of the American forest canopy tree. To overcome this, backcross breeding strategies were initiated by the United States Department of Agriculture and the Connecticut Agricultural Experiment Station. This method used American and Asiatic parentage to produce 
multiple tree lines that were then backcrossed with American chestnut to form advanced hybrids that have American chestnut growth characteristics with putative blight resistance [9]. Field studies coordinated by The American Chestnut Foundation and the US Forest Service are in the process of developing planting strategies for chestnut hybrid introduction into the Appalachian forests of North America [10-12]. In addition, former surfaced mine sites throughout the coal basin of Appalachia offer opportunity for field testing various hybrid lines of American chestnut into $C$. dentata's historic range [13-17]. The notion is that utilizing hybrid chestnut as restoration trees in mine reclamation sites may provide a potentially ecological and economical valuable agroforestry crop on marginal landscapes within Appalachia.

Over $7,000 \mathrm{~km}^{2}$ of historic forest area in the Appalachian region of the US has been mined for coal and reclaimed [18]. Coal mine reclamation initiatives directed by the Surface Mining Control and Reclamation Act of 1977 (SMCRA) regulates that lands used for coal mining be returned to support a productive land cover that was there prior to mining [19]. After the mining operation is completed the left-over coal spoil is buried in place of the extracted coal seam and the remaining overburden, consisting of rocky parent material, is filled and compacted over the buried spoil [20]. To ensure plant establishment, topsoil, that has been either transferred from another mining site or stock piled upon mining, is spread and further graded to match original land contour and seeded with fast establishing herbaceous plants to prevent erosion [21]. However, this results in highly compacted soils with heavy herbaceous competition from nonnative grasses and forbs that slow the recruitment of native pioneer species resulting in a "legacy" of arrested succession in place of native Appalachian forests [22]. To mitigate soil compaction, deep soil ripping $(>1.5 \mathrm{~m})$ have been used in experimental tree plantings. In eastern Ohio, USA, deep soil ripping and chestnut plantings yielded high survival (81-77\%) and tree growth (up to $2 \mathrm{~m}$ ) after five growing seasons [16].

Like other tree species used in coal mine reclamation, American chestnut forms beneficial ectomycorrhizal (ECM) symbioses with root colonizing fungi [23-25]. ECM plants have been found to have a greater access to nitrogen and phosphorus, which may give an establishing plant a competitive advantage when nutrients are limited. ECM colonization has been documented to provide chestnut seedlings with protection from root pathogens (Phytophthora spp.) in greenhouse settings [26] and correlated with diminished root lesions in the field [23]. Extensive research has shown that ECM symbiosis alleviates the impact of highly stressed soils on plant growth by increasing access to water and nutrients to the plant and mitigating the effects of metal toxicity [27-29]. Bauman et al. [30] reported that chestnut seedlings growing on an abandoned mine site with known high levels of heavy metals illustrated significantly lower copper and manganese concentrations in chestnut leaf tissue when colonized by native ECM fungi. In addition, utilizing chestnut with mechanical soil methods on a legacy mine site significantly increased ECM root colonization, fungal species richness, and chestnut seedling growth after two growing seasons [31].

Long-term success using hybrid chestnut as a mine reclamation tree will require the tree's ability to grow above competing vegetation, display adequate field resistance to blight, reproduce, maintain ECM symbiosis, and continue to have tolerance of mine reclamation soils. Chestnuts value as wildlife habitat or a potential agroforestry crop tree will also depend on the tree's ability to sexually reproduce a viable seed source that is safe for the consumption by wildlife and humans. However, Castanea's fast growth and tolerance of heavy metals associated with degraded sites in Asia have resulted in unsafe heavy metal accumulation in edible parts [32]. Because using chestnuts on mine sites in Appalachia is a relatively new practice (less than one decade), little is known about the interaction of hybrid and American chestnut in reclaimed mine soils with regard to plant growth, ECM root colonization, and potential heavy metal uptake in the early stages of establishment. Further, establishing plants can influence changes in rhizosphere chemistry and moisture levels by pulling water from deeper soils by hydraulic lift [33, 34]. As chestnut trees establish over time, it is possible that root exploration for water could result in the translocation of metals from the deeper overburden into the vicinity of the root zone, causing clean soils to become mixed with metals associated with blasted rock and buried spoil. Alternatively, soils may remain relatively clean with minimal heavy metal accumulation in plant tissue, meriting chestnuts use as a potential agroforestry crop on legacy mine sites in the US Eastern forests.

The objective of this current study was to assess tree growth, flowering potential, canker infection, and ECM root colonization among eight-year-old chestnut trees representing three chestnut tree lines: (1) American chestnut ( $C$. dentata), $\mathrm{BC}_{1} \mathrm{~F}_{3}$ chestnut (75\% American chestnut, $25 \%$ Chinese chestnut), and $\mathrm{BC}_{2} \mathrm{~F}_{3}$ chestnut ( $87 \%$ American chestnut and $13 \%$ Chinese chestnut). ECM root colonization was quantified and sorted among most common morphotypes and compared to tree height, flower production, and canker incidence. Also, metal accumulation in drip line soil and plant tissue were analyzed for silver $(\mathrm{Ag})$, aluminum $(\mathrm{Al})$, arsenic (As), cadmium (Cd), copper $(\mathrm{Cu})$, manganese $(\mathrm{Mn})$, lead $(\mathrm{Pb})$, selenium $(\mathrm{Se})$, and zinc $(\mathrm{Zn})$. We hypothesized that metal concentrations among soil, foliage, and floral tissue will not be homogenous and predicted differences in metal uptake and metal translocation within the chestnut tree. Also, if soil metals are a result of hydraulic lift, we predict increased metal concentrations in drip lines of trees when compared to reference site soils that lack plantings of chestnut. Lastly, we hypothesize that ECM root colonization will be negatively correlated to soil heavy metal accumulation within the sampled leaf and flower tissue.

\section{Methods}

2.1. Study Site. The field site used for this study is in the TriValley Wildlife Management Area (TVWMA), Muskingum County, Ohio, USA $\left(40^{\circ} 6^{\prime} 44^{\prime \prime} \mathrm{N},-81^{\circ} 58^{\prime} 23^{\prime \prime} \mathrm{W}\right)$. Experimental blocks were prepared for tree planting using a combination 
of soil ripping and plow and disking. Deep soil ripping was employed using a D-6 dozer with a single-blade $1 \mathrm{~m}$ steel ripper bar attachment crossed-ripped at a $2.5 \mathrm{~m} \times 2.5 \mathrm{~m}$ spacing. The plowed and disked plot was installed using a 250-horse power conventional tractor with chisel plow and disk attachment creating two passes that disturbed the vegetation and tilled soil to a depth of approximately $30 \mathrm{~cm}$. These soil treatments were organized in experimental blocks that were $54 \times 108 \mathrm{~m}$ and replicated three times.

The tree types were comprised of the following seed lines: 507 pure American chestnuts (C. dentata), 257 backcrossed chestnuts $\mathrm{BC}_{1} \mathrm{~F}_{3}$ (backcrossed to create a progeny that is $3 / 4$ th C. dentata and 1/4th C. mollissima), and 423 backcrossed chestnuts $\mathrm{BC}_{2} \mathrm{~F}_{3}$ (backcrossed to create a progeny that is 7/8th C. dentata and $1 / 8$ th C. mollissima). The pure American chestnut seeds were collected from a pure American chestnut stand in Pennsylvania and the backcrossed seeds were openpollinated obtained from the Meadowview Research Farms of The American Chestnut Foundation in Meadowview, VA, USA.

Nuts were sown in March 2006 at the State Nursery in Marietta, Ohio, by the Ohio Department of Natural Resources. Seedlings were germinated in seed beds with soils that were injected with spores of mycorrhizal fungus, Pisolithus tinctorius. Seedlings were nursery grown for one year and then lifted as bare root seedlings in March of 2007. At the time of planting, holes were hand dug by spade shovel, spaced $2.5 \mathrm{~m}$ apart, and the root system of each seedling was dipped in TerraSorb gel to prevent root desiccation. Two fertilizer pellets (20-10-5) were put in each hole and the seedling was backfilled with original soil. A $1 \mathrm{~m} \times 1 \mathrm{~m}$ weed mat was used around each seedling to prevent competition from regenerating herbaceous plant species. Also, a 1.5-m tall chicken wire cage was installed to prevent browse [35].

2.2. Field Data Collection. After eight field seasons, 90 chestnut seedlings, representing each tree type, were randomly selected and evaluated for growth, flowering potential, and the presence of stem cankers caused by $C$. parasitica. Height $(\mathrm{cm})$ was measured using a meter stick from soil level to the apical bud of the main stem. To assess flower production, chestnut trees were scored either 1 (flowers present) or 0 (flowers absent) in June of 2015 for the presence of staminate catkins that developed at the base of the flower branch and/or catkins observed near the apex [36]. Canker incidence was recorded as necrotic bark lesions with the presence of orange spore bearing structures and scored 1 (cankers present) or 0 (cankers absent) [16].

2.3. Soil and Tissue Collection, Digestion, and Elemental Analysis. Soil and plant tissue were also collected at this time. Leaves were collected from 90 trees that were randomly selected to represent 30 of each tree type. A 30-cm segment of a top branch, which represented new growth, was removed with a pair of hand pruners. Of these, 23 individuals were flowering and those flowers (both male and female) were collected. Of these flowers, 9 were $\mathrm{BC}_{1} \mathrm{~F}_{3}, 7$ were $\mathrm{BC}_{2} \mathrm{~F}_{3}$, and 7 were American chestnut. To assess differences in the accumulation of metals and arsenic in soils by tree type, soil sampling locations were randomly selected across plots and collected at the drip line of 36 seedlings (12 per tree type). Nine reference soils cores were also collected. Reference soils are defined as soils that were located $20 \mathrm{~m}$ adjacent to each block and did not receive a soil preparation method or a planted chestnut tree. The vegetation in reference soils were comprised of the plant material used to originally reclaim the site, which was predominately tall fescue (Festuca arundinacea), Kentucky blue grass (Poa pratensis), and Chinese lespedeza (Lespedeza cuneata).

Soil was collected using a soil probe $(2.5 \mathrm{~cm}$ in diameter) at a depth of $18 \mathrm{~cm}$. In the laboratory, plant tissue was washed, and both tissue and soil were oven-dried and homogenized using a mortar and pestle. Approximately 0.1 grams of the dried samples was digested in concentrated nitric acid at $170^{\circ} \mathrm{C}$ in Teflon ${ }^{\circledR}$ lined vessels in a CEM Mars 5 microwave digester and then diluted five times with water. Samples were analyzed for silver (Ag), aluminum (Al), arsenic (As), cadmium $(\mathrm{Cd})$, copper $(\mathrm{Cu})$, manganese $(\mathrm{Mn})$, lead $(\mathrm{Pb})$, and zinc (Zn) using inductively coupled plasma-mass spectrometry (ICP-MS) at the Community Innovation Zone Laboratory at the University of Washington, Tacoma, WA.

2.4. ECM Colonization and Morphotyping to Category. Roots samples were collected from the drip line of a subsample of the chestnuts selected for foliar and soil sampling $\left(13 \mathrm{BC}_{1} \mathrm{~F}_{3}\right.$, $23 \mathrm{BC}_{2} \mathrm{~F}_{3}$, and 17 American chestnut). In the laboratory, samples were washed using distilled water, cut into $3 \mathrm{~cm}$ segments, and stored in Petri dishes at $4^{\circ} \mathrm{C}$ for 12 days. All samples were observed under a dissecting microscope for ectomycorrhizal formation determined by the presence of a fungal sheath. One hundred root tips per seedling were randomly selected from root segments. Using a grid template as a guide, the number of ECM root tips was divided by the total number of roots sampled up to 100 tips to calculate percent ECM root colonization. ECM colonization was morphotyped based on color and texture of sheath, emanating hyphae, and presence of rhizomorphs [31]. Morphotypes were quantified and assigned to one of three categories: (1) <25\% ECM root colonization, (2) black hyphae and sheath (Figure 1(a)), and (3) abundant white hyphae (Figures 1(b)-1(d)).

Two samples per white morphotype were selected for DNA extraction. A three-mm segment of root tip was removed and transferred into a microcentifuge tube and stored at $-70^{\circ} \mathrm{C}$ until extraction. The $3 \mathrm{~mm}$ segment was homogenized using a bead beater and DNA was extracted using QIAgen's DNeasy Plant Mini Kit per manufactures protocol. About $10 \mathrm{ng}$ of this DNA was used in PCR reactions using primers ITS1-F ( $5^{\prime}$ cttggtcatttagaggaagtaa $\left.3^{\prime}\right)$ and ITS4 $\left(5^{\prime}\right.$ tcctccgcttattgatatgc $\left.3^{\prime}\right)$, which amplify the highly variable internal transcribed spacer (ITS) region of ECM fungal ribosomal DNA (rDNA) [37, 38]. The PCR products were purified using Wizard ${ }^{\circledR}$ SV 96 Genomic DNA Purification System (Promega, USA) and used for DNA sequencing. Sanger sequencing was performed by capillary sequencing at the Plant-Microbe Genomics Facility of The Ohio State University (Columbus, OH, USA) using The Applied Biosystem ABI Prism 3730 DNA Analyzer. Of these, 22 sequences were analyzed and edited using the Sequencher 4.2 software (Gene 


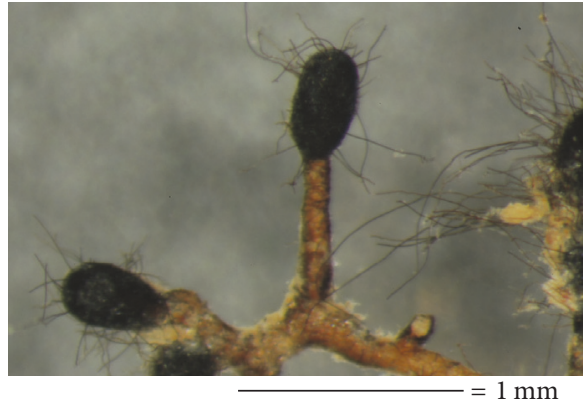

(a)

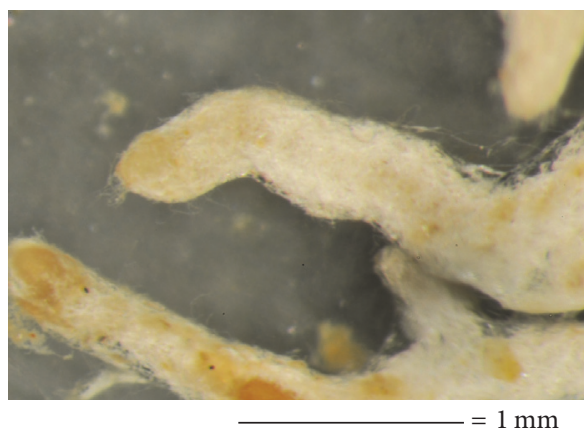

(c)

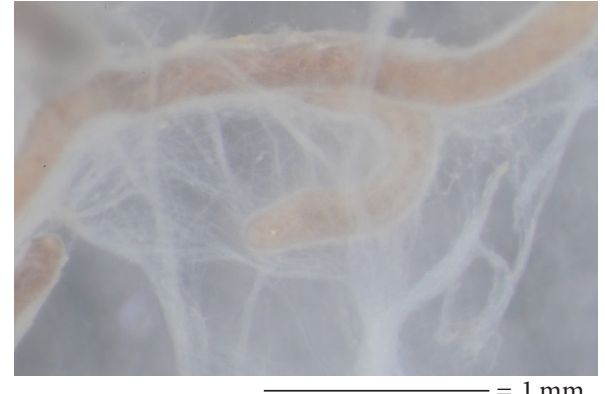

(b)

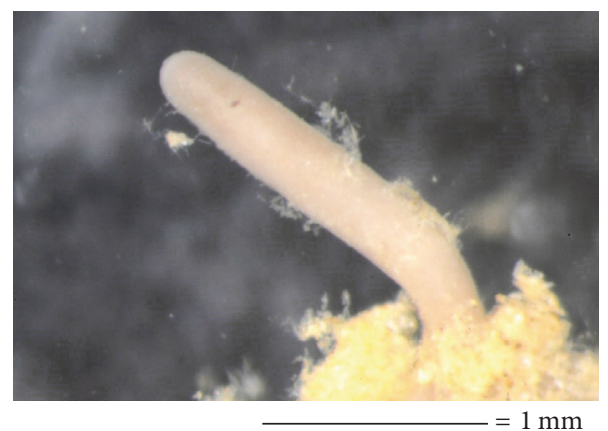

(d)

FIGURE 1: Photographed (45x) ECM morphotypes sampled from American chestnut root tips from a reclaimed mine site in Dresden OH, USA. Panels display the following that were matched to vouchered genera sequences in GenBank: Panel (a) Cenococcum sp. on C. dentata, Panel (b) Cortinarius sp. on hybrid $\mathrm{BC}_{1} \mathrm{~F}_{3}$, Panel (c) Scleroderma sp. on hybrid $\mathrm{BC}_{2} \mathrm{~F}_{3}$, and Panel (d) Russula sp. on C. dentata. Bar $=1$ mm.

Codes, Ann Arbor, Michigan) and queried to those present in the GenBank for fungal genera [39]. These matched Cortinarius, Scleroderma, and Russula genera. Fungi colonizing $<25 \%$ of the chestnut roots were not sequenced at this time and are currently part of a larger study characterizing ECM community composition.

2.5. Statistical Analysis. Growth and ECM colonization among tree types were assessed using an analysis of variance (ANOVA) followed by Tukey's HSD (Honestly Significant Difference). To compare presence of flowering trees and chestnut blight cankered trees by seedling type and ECM morphological categories, a Pearson's Chi-Square $\left(X^{2}\right)$ was used. Differences in soil and foliage metal concentrations were analyzed using two-way analysis of variance where Block and Tree type (pure American, $\mathrm{BC}_{1} \mathrm{~F}_{3}$, and $\mathrm{BC}_{2} \mathrm{~F}_{3}$ ) were examined as main effects along with their interaction (Block * Tree type) using Type II ANOVA [40]. All residuals were examined for the assumption of normality and homogeneity of variance using quantile-quantile plots and histograms.

Mean metal concentrations in soil and chestnut tissue are reported with $95 \%$ confidence intervals and compared to site reference soils, Muskingum County soils, and Ohio mean background levels collected from 36 Ohio counties [4143] and US topsoil ranges [44]. Metal concentrations were also used to calculate a Biological Accumulation Coefficient (BAC). To calculate this, the metal concentration of the leaf and floral tissue is divided by the same metal content in the soil [32] as in the following equation:

$$
\mathrm{BAC}=\frac{\text { leaf and floral tissue }}{\text { metal content in the soil }} .
$$

BAC was then correlated to percent ECM root colonization. Pearson correlation analysis was used to compare the strength of relationships between ECM root colonization and BAC for each of the elements: $\mathrm{Ag}, \mathrm{Al}, \mathrm{As}, \mathrm{Cd}, \mathrm{Cu}, \mathrm{Mn}, \mathrm{Pb}$, and $\mathrm{Zn}$. To analyze differences in metal concentrations between soils and foliage and for foliage and floral tissue, a paired $t$ test was used due to unequal variances. When required, a log data transformation was used to meet the assumption of a normal distribution. All statistical analyses were performed using JMP software (12.0, SAS Institute, Cary NC, USA).

\section{Results}

3.1. Comparison of Growth, Survival, Flower and Canker Production, and ECM Colonization. When survival was compared among tree types, $\mathrm{BC}_{2} \mathrm{~F}_{3}$ had the greatest survival $\left(80 \% ; X^{2}=10.0, \mathrm{df}=2, P=0.006\right)$. American chestnut was significantly taller than both hybrid lines $(F(2,85)=$ $3.39, P=0.03$; Table 1). Further, American chestnut had significantly more cankers ( $15 \%$ of trees) when compared to both hybrids (5 and 7\%; $X^{2}=20.0 \mathrm{df}=2, P<0.0001$ ). No differences existed when flowering or percent ECM root colonization was compared among the tree types (Table 1). 
TABLE 1: Comparison of survival, height, flowers, cankers, and percent ectomycorrhizal (ECM) fungal root colonization on eight-year-old chestnut tree types (pure American, $\mathrm{BC}_{1} \mathrm{~F}_{3}$, and $\mathrm{BC}_{2} \mathrm{~F}_{3}$ ) on a reclaimed mine site in Dresden $\mathrm{OH}$, USA. Means sharing common letters do not significantly differ at $\alpha=0.05$ to Tukey's HSD.

\begin{tabular}{|c|c|c|c|c|c|}
\hline Chestnut tree type & Surviving trees & Mean HT $(\mathrm{cm}) \pm \mathrm{SE}$ & Trees flowering & Trees with cankers & $\% \mathrm{ECM}$ \\
\hline $\mathrm{BC}_{1} \mathrm{~F}_{3}$ & $72 \%^{\mathrm{b}}$ & $225 \pm 19^{\mathrm{b}}$ & $40 \%^{\mathrm{a}}$ & $5 \%^{\mathrm{a}}$ & $46 \pm 9^{a}$ \\
\hline $\mathrm{BC}_{2} \mathrm{~F}_{3}$ & $80 \%^{\mathrm{a}}$ & $232 \pm 22^{b}$ & $38 \%^{\mathrm{a}}$ & $7 \%^{a}$ & $59 \pm 9^{\mathrm{a}}$ \\
\hline American & $70 \%^{b}$ & $296 \pm 22^{\mathrm{a}}$ & $36 \%^{\mathrm{a}}$ & $15 \%^{\mathrm{b}}$ & $56 \pm 6^{\mathrm{a}}$ \\
\hline
\end{tabular}

TABLE 2: Eight-year-old chestnut trees (tree types pooled) compared by three ECM categories: (1) those with <25\% ECM root colonization $(n=19),(2)$ colonization greater than $25 \%$ with black hyphae and sheaths $(n=18)$, and (3) colonization greater than $25 \%$ with white hyphae and fungal sheaths $(n=13)$. Error bars are \pm 1 standard error and different letters indicate statistical differences at 0.05 .

\begin{tabular}{lccc}
\hline ECM morphological categories & Mean \% ECM colonization & \% ECM range & Chestnut tree height $(\mathrm{cm})$ \\
\hline$<25 \%$ colonization & 8.4 & $0-21.3$ & $205.2 \pm 22.3^{\mathrm{b}}$ \\
$>25 \%$ black morphology & 61.2 & $31-91.3$ & $300.2 \pm 29.9^{\mathrm{a}}$ \\
$>25 \%$ white morphology & 51.0 & $33.8-84.5$ & $282.3 \pm 25.7^{\mathrm{a}}$ \\
\hline
\end{tabular}

3.2. ECM Morphotypes and Attributes. Of the 54 root samples collected, 50 were mycorrhizal. ECM colonization averaged $54 \%$ on roots and did not differ among the tree types. Morphotypes were assigned to one of three categories and then quantified. The three categories were (1) ECM $<25 \%$ root colonization $(n=18)$, (2) black mantel with radiating black hyphae ( $n=19$; Figure 1(a)), or (3) white mantel with radiating white hyphae $(n=13$; Figures $1(\mathrm{~b})-1(\mathrm{~d}))$. Of these, 22 sequences were analyzed and match vouchered specimens in GenBank to genera. The morphology of the black hyphae consistently matched Cenococcum sp. and represented $38 \%$ of all roots sampled. Of the white morphotypes, which represented $26 \%$ of all roots sampled, eight sequences matched two Cortinarius spp., three sequences matched one Scleroderma sp., and two sequences matched one Russula sp.

When chestnut tree types were compared to ECM morphological categories, no differences existed $\left(X^{2}=3.37\right.$, $P=0.50)$. No differences existed when ECM morphological categories were compared to flowering $\left(X^{2}=3.60, P=\right.$ $0.16)$ or cankering trees $\left(X^{2}=0.93, P=0.62\right)$. Eightyear-old chestnut tree roots colonized by either black or white fungal mantels were significantly taller $(\mathrm{cm})$ than trees colonized with less than $25 \% \operatorname{ECM}\left(F_{(2,44)}=4.23\right.$, $P=0.02$; Table 2). When ECM morphological categories were compared with regard to bioaccumulation of metals and arsenic, no differences existed. However, when ECM colonization (morphotypes pooled) was correlated to the bioaccumulation of soil elements, ECM colonization was significantly positively correlated to aluminum $(r=0.48$, $P=0.01$; Table 3 ).

3.3. Soils Compared to County, State, and US Soil Range. Elemental concentrations in drip line soils that were less than reference site soils included arsenic and cadmium $(P=$ 0.03 and 0.04 , respectively; Table 4$)$. Authors note marginal significance detected for lower selenium levels for Se $(P=$ 0.08). Most elements such as $\mathrm{Ag}, \mathrm{Al}, \mathrm{As}, \mathrm{Cu}, \mathrm{Mn}, \mathrm{Se}$, and $\mathrm{Zn}$ were higher than county and state averages. However,
TABLE 3: Correlations reported with correlation coefficients $(r)$ and $P$ values $(P)$ between ECM root colonization and bioaccumulation of elements from eight-year-old chestnut trees (tree type pooled, $n=$ $24)$. Asterisks $(* *)$ indicate differences at 0.05 .

\begin{tabular}{lcc}
\hline \multirow{2}{*}{ Elements } & \multicolumn{2}{c}{ Bioaccumulation statistics } \\
& $r$ & $P$ \\
\hline $\mathrm{Ag}$ & -0.11 & 0.60 \\
$\mathrm{Al}$ & 0.48 & $0.01^{* *}$ \\
$\mathrm{Cu}$ & 0.22 & 0.30 \\
$\mathrm{~Pb}$ & 0.02 & 0.94 \\
$\mathrm{Se}$ & 0.20 & 0.41 \\
$\mathrm{Zn}$ & -0.02 & 0.91 \\
\hline
\end{tabular}

the means for soil concentrations ( $\mathrm{Ag}, \mathrm{Al}, \mathrm{As}, \mathrm{Cu}$, and $\mathrm{Mn}$ ) are considered in the lower range for common topsoil in the continental United States (Table 4).

3.4. Elemental Concentrations of Drip Line, Leaf, and Flower Tissue. Few differences existed when elemental soil concentrations among the blocks and tree types were compared (Table 5). Marginal block effects for manganese and zinc were noted. No differences existed when leaf and flower tissue were compared among tree types. However, block effects existed for selenium in leaf and flower tissue $(P=0.007$ and 0.004$)$, as well as silver concentrations in leaf tissue $(P=0.003$; Table 5). No differences were detected in bioaccumulation of elements in leaf tissue from soil.

Differences in elemental concentrations were detected between soil and leaf tissue for arsenic, cadmium, lead, aluminum, copper, and silver (all $P<0.05$; Figure 2). Arsenic and cadmium were present in drip line soils below the reference soils from the field site but were not detected in leaf tissue (Figures 2(a) and 2(b)). Further, there was little concentration of lead and aluminum in leaf tissue, though both metals were present in the soils in similar concentrations to the reference sites (Figures 2(c) and 2(d)). 
TABLE 4: Mean concentrations of metals in drip line soils (mean ppm) with 95\% confidence intervals (95\% CI) compared with reference soils that were collected on site (no chestnuts planted), average background metal concentration in Ohio soils (ppm) [41], averages in Muskingum County [42, 43], and US topsoil ranges [44]. Asterisks $(* *)$ indicate differences at 0.05 .

\begin{tabular}{|c|c|c|c|c|c|c|}
\hline Element analyzed & $\begin{array}{c}\text { Drip line } \\
\text { mean (ppm) }\end{array}$ & $\begin{array}{l}\text { Drip line } \\
95 \% \text { CI }\end{array}$ & Site reference & $\begin{array}{c}\text { County } \\
\text { ave (ppm) }\end{array}$ & $\begin{array}{l}\text { Ohio soil } \\
\text { (ppm) }\end{array}$ & $\begin{array}{c}\text { US topsoil } \\
\text { range (ppm) }\end{array}$ \\
\hline $\mathrm{Ag}$ & 0.45 & {$[0.30,0.74]$} & 0.24 & $<1$ & 0.25 & $0.01-5$ \\
\hline $\mathrm{Al}$ & 11,172 & {$[9,909,13,261]$} & 9983.4 & NA & 7,685 & $10,000-300,000$ \\
\hline As & $10.62^{* *}$ & {$[8.68,11.07]$} & 12.78 & 7.9 & 5.72 & $0.1-55$ \\
\hline $\mathrm{Cd}$ & $0.21^{* *}$ & {$[0.13,0.24]$} & 0.27 & 0.2 & 0.507 & $0.1-1$ \\
\hline $\mathrm{Cu}$ & 26.0 & {$[21.60,32.25]$} & 23.38 & 16 & 12 & $2-50$ \\
\hline $\mathrm{Mn}$ & 767.84 & {$[644.5,915.7]$} & 732.68 & 459 & 459 & $600-6,000$ \\
\hline $\mathrm{Pb}$ & 14.37 & {$[12.70,15.94]$} & 14.54 & 28 & 16.2 & $22-44$ \\
\hline $\mathrm{Se}$ & $3.55^{*}$ & {$[2.05,4.25]$} & 4.71 & 0.3 & 0.25 & $0.1-3.9$ \\
\hline $\mathrm{Zn}$ & 75.07 & {$[64.35,92.0]$} & 66.18 & 65 & 42.7 & $10-100$ \\
\hline
\end{tabular}

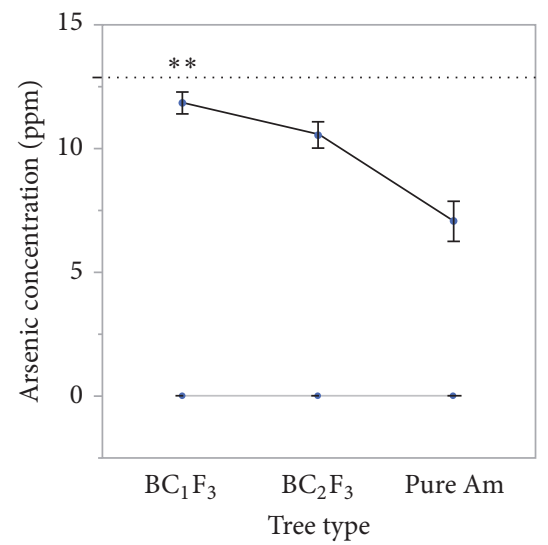

(a)

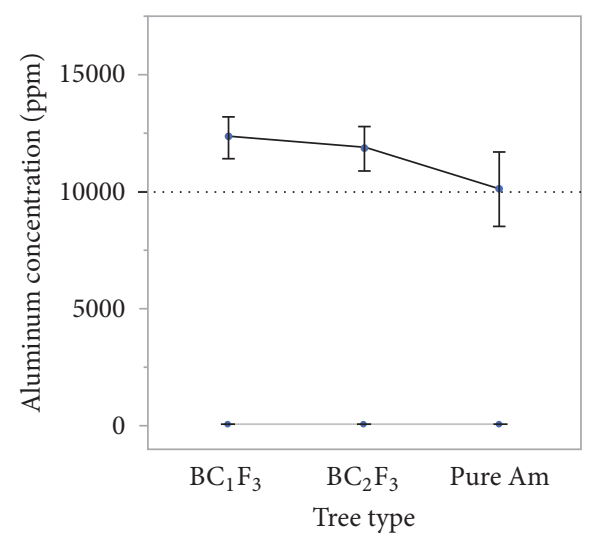

(d)

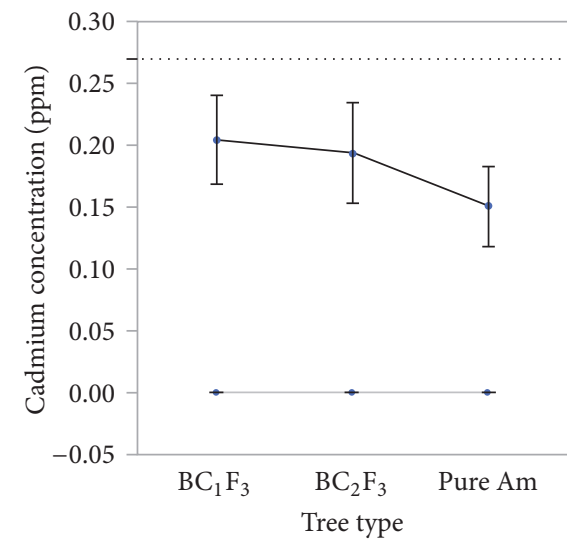

(b)

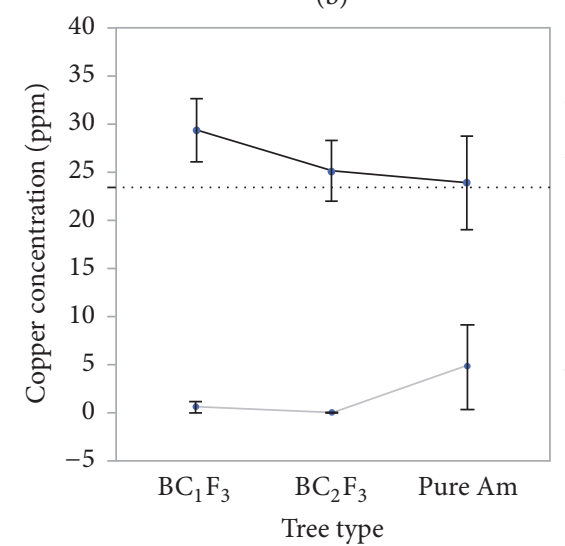

(e)

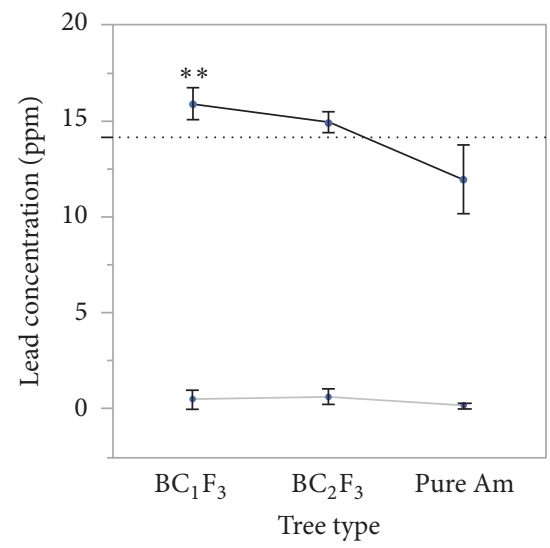

(c)

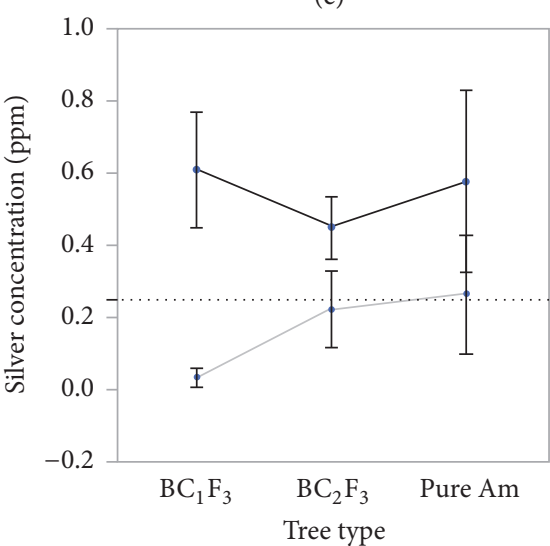

(f)

Chestnut tree types after eight growing seasons

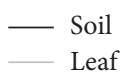

FIGURE 2: Mean soil (black lines) and leaf tissue (gray lines) concentrations of the six elements (As, $\mathrm{Cd}, \mathrm{Pb}, \mathrm{Al}, \mathrm{Cu}, \mathrm{and} \mathrm{Ag}$ ) that differed in concentration from soil to tissue by chestnut tree types (pure American, $\mathrm{BC}_{1} \mathrm{~F}_{3}$, and $\mathrm{BC}_{2} \mathrm{~F}_{3}$ ) in Dresden, OH, USA $(n=29)$. Soils collected from the reference plots without tree plantings are illustrated as dotted lines on the graph. Asterisks $(* *)$ indicate differences at 0.05 . 
TABLE 5: Two-way analysis of variance results for soil, leaf, flower, and bioaccumulation of each metal concentration by block and tree type at Tri-Valley Wildlife Management Area, Dresden, $\mathrm{OH}$. Response variables were block and tree type (pure $\mathrm{American}_{2} \mathrm{BC}_{1} \mathrm{~F}_{3}$, and $\mathrm{BC}_{2} \mathrm{~F}_{3}$ ). Superscripts indicate required data transformations to achieve residual normality. Dashes $(-)$ indicate levels that were an insufficient sample size for analysis due to concentration levels below detection limit. Asterisks $(* *)$ indicate differences at 0.05 with single asterisk $(*)$ noting marginal significance.

\begin{tabular}{|c|c|c|c|c|}
\hline Metal & $\begin{array}{c}\text { Soil } \\
P \\
\end{array}$ & $\begin{array}{c}\text { Leaf } \\
P\end{array}$ & $\begin{array}{c}\text { Flower } \\
P \\
\end{array}$ & $\begin{array}{c}\text { Bioaccumulation } \\
P \\
\end{array}$ \\
\hline \multicolumn{5}{|l|}{$\overline{\mathrm{Ag}^{1}}$} \\
\hline Block & 0.48 & 0.46 & $0.003^{* *}$ & 0.37 \\
\hline Tree type & 0.81 & 0.41 & 0.18 & 0.48 \\
\hline Block: tree type & 0.59 & 0.58 & $0.041^{* *}$ & 0.93 \\
\hline \multicolumn{5}{|l|}{$\mathrm{Al}^{1}$} \\
\hline Block & 0.88 & 0.59 & 0.63 & 0.35 \\
\hline Tree type & 0.50 & 0.62 & 0.71 & 0.62 \\
\hline Block: tree type & 0.68 & 0.78 & 0.89 & 0.68 \\
\hline \multicolumn{5}{|l|}{ As } \\
\hline Block & 0.98 & & & \\
\hline Tree type & $0.001^{* *}$ & - & - & - \\
\hline Block: tree type & 0.64 & & & \\
\hline \multicolumn{5}{|l|}{$\mathrm{Cd}$} \\
\hline Block & 0.83 & & & \\
\hline Tree type & 0.59 & - & - & - \\
\hline Block: tree type & 0.68 & & & \\
\hline \multicolumn{5}{|l|}{$\mathrm{Cu}^{1}$} \\
\hline Block & 0.41 & & 0.37 & \\
\hline Tree type & 0.70 & - & 0.91 & - \\
\hline Block: tree type & 0.83 & & 0.42 & \\
\hline \multicolumn{5}{|l|}{$\mathrm{Mn} 55^{1}$} \\
\hline Block & $0.07^{*}$ & 0.99 & 0.57 & 0.44 \\
\hline Tree type & 0.15 & 0.90 & 0.71 & 0.99 \\
\hline Block: tree type & 0.55 & 0.45 & 0.51 & 0.63 \\
\hline \multicolumn{5}{|l|}{$\mathrm{Pb}$} \\
\hline Block & 0.44 & & & 0.88 \\
\hline Tree type & $0.05^{* *}$ & - & - & 0.89 \\
\hline Block: tree type & 0.93 & & & 0.62 \\
\hline \multicolumn{5}{|l|}{$\mathrm{Se}$} \\
\hline Block & 0.32 & $0.007^{* *}$ & $0.004^{* *}$ & 0.26 \\
\hline Tree type & 0.51 & 0.94 & 0.39 & 0.63 \\
\hline Block: tree type & 0.54 & 0.97 & $0.03^{* *}$ & 0.66 \\
\hline \multicolumn{5}{|l|}{$\mathrm{Zn}$} \\
\hline Block & $0.06^{*}$ & 0.71 & 0.77 & 0.84 \\
\hline Tree type & 0.3568 & 0.68 & 0.83 & 0.84 \\
\hline Block: tree type & 0.5221 & 0.53 & 0.62 & 0.74 \\
\hline
\end{tabular}

${ }^{1}$ Data square root transformed to achieve residual normality.

Hybrids $\mathrm{BC}_{1} \mathrm{~F}_{3}$ and $\mathrm{BC}_{2} \mathrm{~F}_{3}$ had significantly greater drip line soil concentrations of arsenic (As; $\left.F_{(2,26)}=14.38, P<0.0001\right)$ and lead $\left(\mathrm{Pb} ; F_{(2,26)}=3.44, P=0.05 ;\right)$ than soils of American chestnut trees (Figures 2(a) and 2(c)). Silver was unique; it was higher in concentration in drip line soils when compared to reference sites with adequate uptake in tissue (Figure 2(f)).

3.5. Comparison of Metals in Foliage and Flowers by Tree Type. Similar to leaf tissue, there were no detectable levels of arsenic or cadmium in flower tissue. Also, similar trace concentrations between foliage and floral tissue were observed with lead, silver, and zinc (Table 6). Differences between the chestnut tissues were detected among manganese, aluminum, copper, and selenium. Manganese $(t=3.27, \mathrm{df}=22, P=$ $0.003)$ and aluminum $(t=2.86, \mathrm{df}=22, P=0.009)$ had significantly higher concentrations in foliage than in floral tissue (Figures 3(a) and 3(b)). Conversely, copper $(t=-4.83$, $\mathrm{df}=22, P<0.0001)$ and selenium $(t=-3.46, \mathrm{df}=22$, 
TABLE 6: Mean concentrations of metals in foliage and floral tissue of chestnuts (pure American, $\mathrm{BC}_{1} \mathrm{~F}_{3}$, and $\mathrm{BC}_{2} \mathrm{~F}_{3}$ ) growing in the Tri-Valley Research Site as compared with ranges of metals in plant tissue ( $\mathrm{ppm})$ as reported in the literature [45-49]. $\mathrm{BDL}=$ below detection limit.

\begin{tabular}{|c|c|c|c|c|c|}
\hline Element & $\begin{array}{c}\text { Chestnut } \\
\text { foliage (ppm) }\end{array}$ & $95 \% \mathrm{CI}$ & Chestnut floral (ppm) & $95 \% \mathrm{CI}$ & Range in plant tissues \\
\hline $\mathrm{Ag}$ & 0.15 & {$[0.06,0.24]$} & 0.11 & {$[0,0.22]$} & $0.05-1.5$ \\
\hline $\mathrm{Al}$ & 74.83 & {$[58.96,90.71]$} & 41.70 & {$[17.47,65.90]$} & $30-250$ \\
\hline As & $\mathrm{BDL}$ & - & BDL & - & $0.009-1.5$ \\
\hline $\mathrm{Cd}$ & $\mathrm{BDL}$ & - & BDL & - & $0.1-2.4$ \\
\hline $\mathrm{Cu}$ & 0.91 & {$[-0.5,2.34]$} & 23.90 & {$[14.35,33.38]$} & $4-15$ \\
\hline Mn55 & 965.18 & {$[823.7,1106.7]$} & 662.08 & {$[544.75,779.41]$} & $20-400$ \\
\hline $\mathrm{Pb}$ & 0.48 & [0-0.97] & 0.37 & {$[-0.21,0.95]$} & $0.1-10$ \\
\hline $\mathrm{Se}$ & 2.48 & {$[1.36,3.6]$} & 7.12 & {$[5.50,8.74]$} & $<10$ \\
\hline $\mathrm{Zn}$ & 64.79 & {$[29.19,100.39]$} & 58.0 & {$[14.51,101.39]$} & $27-100$ \\
\hline
\end{tabular}

$P=0.002)$ were in higher concentrations within the floral tissue than leaf tissues (Table 6; Figures 3(c) and 3(d)). No consistent patterns existed that illustrate potential trends in metal acquisition by tree type.

\section{Discussion}

After eight years, American chestnut trees were taller than both hybrid lines; however, hybrid $\mathrm{BC}_{2} \mathrm{~F}_{3}$ had the greatest survival, which was similar to what was reported after 5 years [16]. When compared to other tree species on a SMCRA ripped site in West Virginia, chestnut survival was greater than other species such as red oak, black walnut, and black cherry [50]. However, when compared to 8-year-old American chestnut trees grown in cultivated Wisconsin soils, the American chestnut trees ( $3.0 \mathrm{~m}$ average heights) were less than the $8 \mathrm{~m}$ growth reported by Jacobs et al. [51]. This growth comparison illustrates the challenges faced when planted in disturbed reclamation soils that are low in biological activity, organic matter, and nutrition. In addition, natural canker incidence was greater on American chestnuts than the two hybrid tree types, which impacted average heights.

Differences were not detected among tree types regarding individuals flowering. This merits further examination in nut production with regard to the viability, nutritional analysis, and metal concentrations in nut tissue. This coincidental flowering may suggest the ability for natural backcrossing in the field; however, receptive stigma and viable pollen among the tree types were not tested at this time. Some chestnut trees may exhibit flowering as a stress response in the presence of blight, drought, poor soil nutrition, and herbaceous competition. The larger trees will more likely have the carbon resources available for production of viable seed; however, further study is needed to confirm bur and nut development. Cankers often begin to appear on chestnut trees around the same time they begin to produce nuts. However, even in blighted stands, mast production from mature trees has been reported to be $2,758.5$ per $\mathrm{kg} \mathrm{ha}^{-1}$ in a mature forest [52]. As chestnut blight spreads through the stand, increased mortality of pure American seedlings can be predicted while anticipating some loss of the hybrid seed types. Eventually, chestnut blight will drive selection of breeding lines that display varying levels of blight resistance; seed types that lack genes for resistance will eventually fail to reproduce while trees with adequate blight resistance will increase in population.

Differences were not detected among tree types regarding ECM colonization. Thirty-eight percent of our samples were categorized as ECM with black fungal sheaths and hyphae, which matched Cenococcum morphology and DNA sequence. Cenococcum shares morphologies of ascomycetes ECM such as short-ranging, nonaggregated, dark mycelia with thick, melanized cell walls, which may play a vital role in protecting tissue against environmental stressors such as UV radiation, heavy metals, and water stress $[53,54]$. Twentysix percent of ECM samples were characterized as abundant white sheaths and hyphae which matched sequences in Cortinarius, Scleroderma, and Russula genera. The majority of the white hyphal group were sequenced to two Cortinarius genera and were observed as forming dense hydrophobic hyphal cords and rhizomorphs, assumed to be efficient in moving materials over relatively large distances $[55,56]$. Other white hyphal morphology belonged to Scleroderma genera which produced thick rhizomorphs that has been reported to improve growth and deter heavy metal accumulation in foliage [30]. Lastly, one Russula species was found colonizing on two of the chestnut root samples categorized as white hypha. This genus has been reported on chestnut in temperate forest ecosystems and is more prevalent in undisturbed habitats and mature American chestnut roots [57].

Regarding ECM colonization, trees that had less than $25 \%$ ECM root colonization were significantly shorter than black and white hyphal morphologies (both colonized greater than $50 \%$ ). This was consistent with the need of $40 \%$ root colonization for the host plant to receive benefits from an ECM fungus [58, 59]. However, authors note that it is not clear whether ECM colonization was the driver of increased plant height or rather if larger trees contributed to an increase in ECM colonization [31]; regardless, both are indicative of healthy tree establishment on this site. Chestnuts seedlings that did not perform as well on this site may not have been 


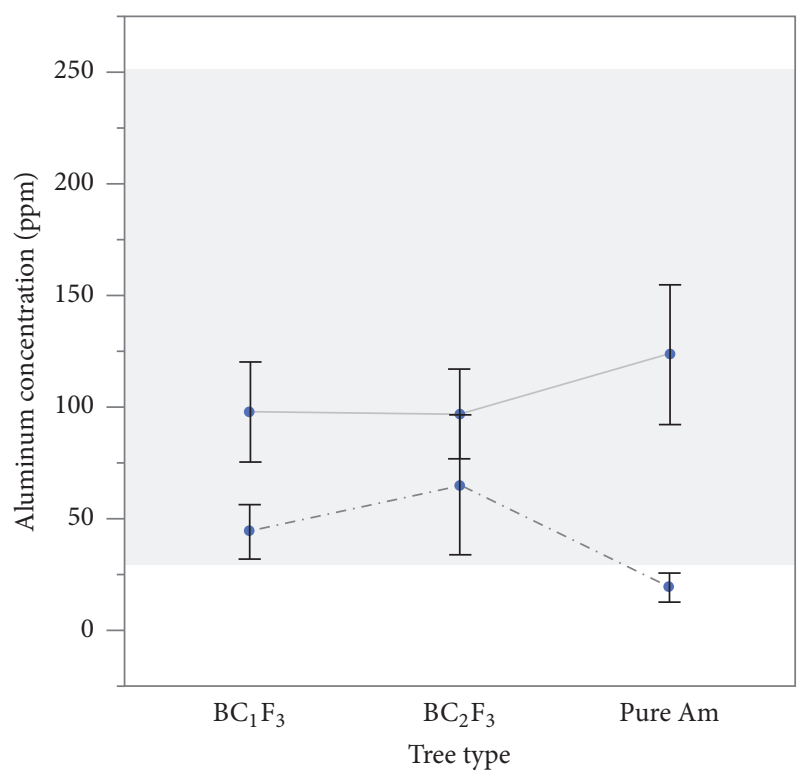

(a)

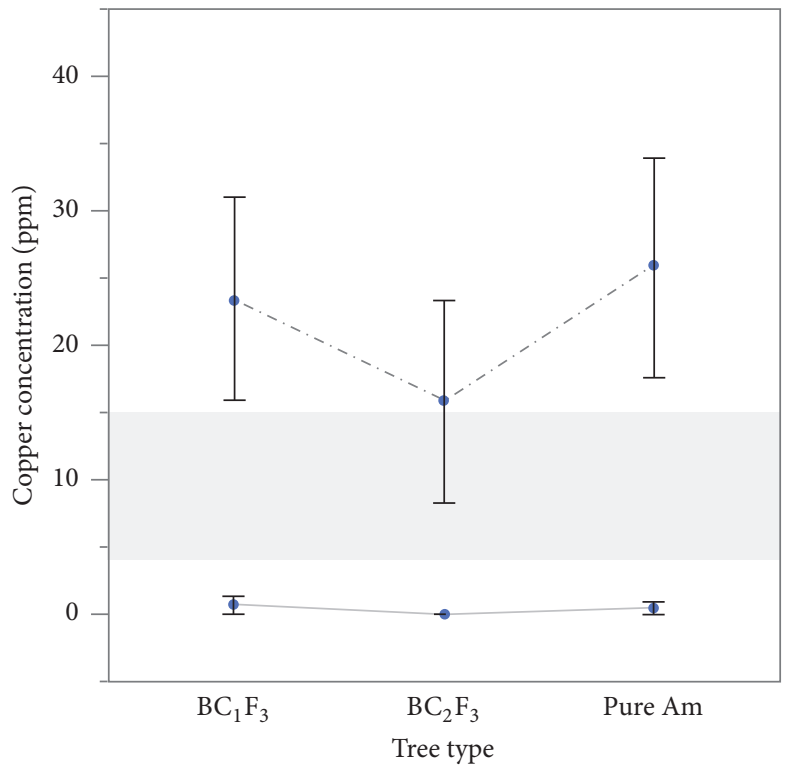

(c)

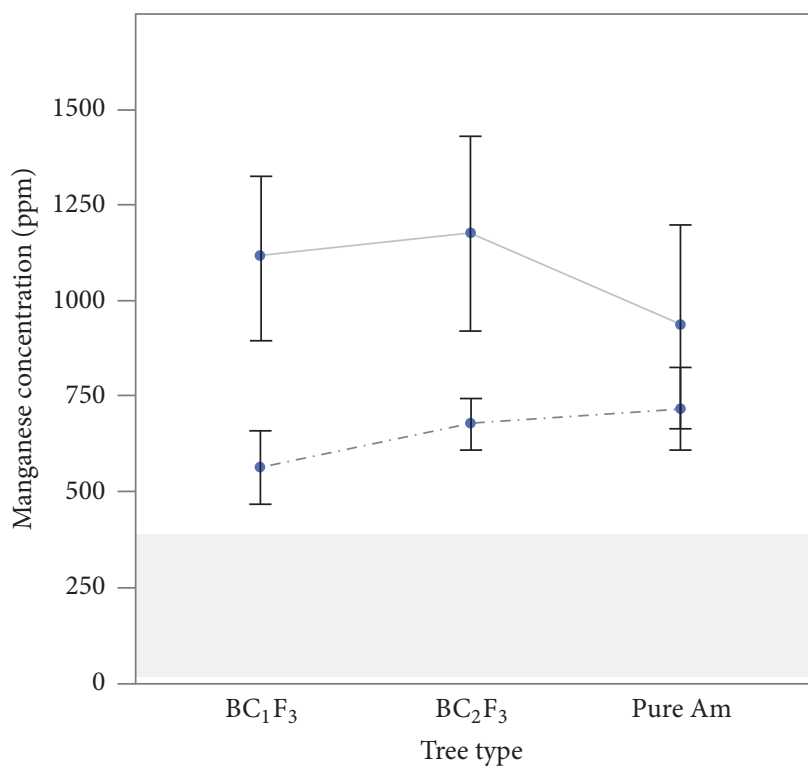

(b)

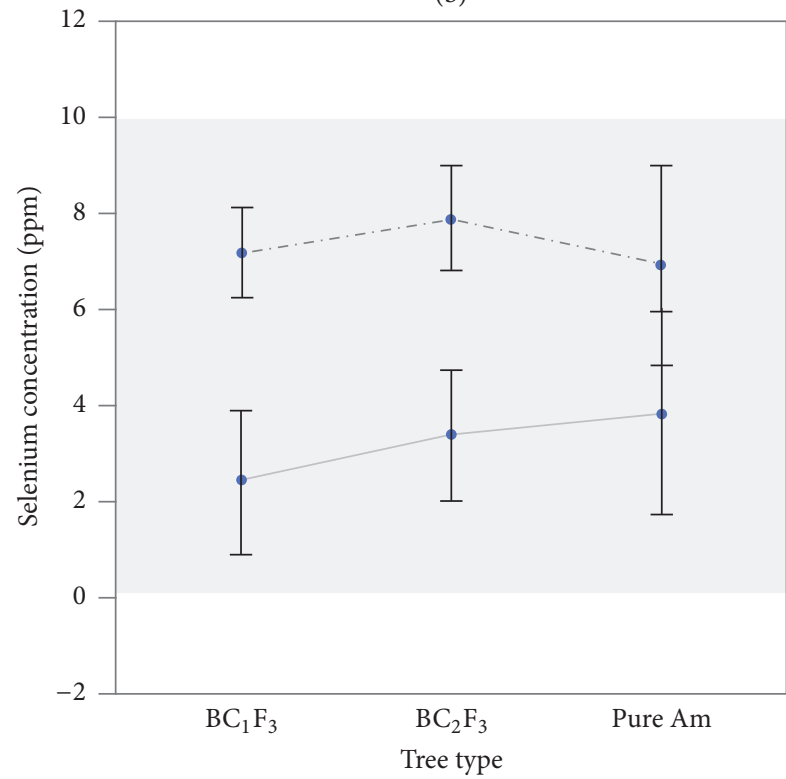

(d)

Chestnut tree types after eight growing seasons

Leaf

-.- Flower

FIGURE 3: Mean leaf tissue (gray lines) and floral tissue (broken dark gray) metal concentrations $(n=22)$ by chestnut tree type (pure American, $\mathrm{BC}_{1} \mathrm{~F}_{3}$, and $\left.\mathrm{BC}_{2} \mathrm{~F}_{3}\right)$ in Dresden, $\mathrm{OH}$, USA. Common range in plant tissue is illustrated with a gray band on the graph.

able to produce enough carbon to support greater than $25 \%$ root colonization by ECM fungi, assuming carbon limitation as a mechanism behind the decrease in ECM colonization $[60,61]$. Additionally, elements needed for plant growth in trace amounts ( $\mathrm{Ag}, \mathrm{Al}, \mathrm{Mn}$, and $\mathrm{Pb}$ ) were found to be in relatively low concentrations in this field site. Of these, this study documented a significantly positive relationship with percent ECM root colonization and the bioaccumulation of Al.
In general, soils on this reclaimed site were not high in metals, which is consistent with the notion that reclamation under SMCRA has led to some immediate improvements such as deterring heavy metals from entering the environment [62]. There was one exception; selenium, indicative of coal spoil, was higher than county and state averages and in the higher concentration range of common US soils. Also noted, drip lines were significantly lower in selenium than reference soils (soils lacking tree plantings or soil preparation 
methods). This may indicate that chestnuts may be improving soil conditions by removing Se and not contaminating drip lines with contaminants associated with buried soil by hydraulic lift. Selenium accumulated in normal levels in plant leaf tissue (0.51-3.19), however, was elevated in floral tissue (5.78-8.85 ppm). Importantly, Se can biomagnify in ecosystems [63] and it has been suggested that 4 ppm of selenium in plants is the tolerance limit for animals and levels above 5 ppm could be a concern [64]. Although we did not test levels in chestnut seed, we found floral tissue to average $7.3 \mathrm{ppm}$, which may merit closer inspection of the developing chestnut seed on legacy sites. Further, significant block effects for soil concentrations of selenium and zinc illustrate variability in reclaimed soils and require further monitoring throughout other legacy and reclaimed sites selected for chestnut plantings in Appalachia.

After eight growing seasons, no difference existed in elemental levels in plant tissue among the chestnut types. Further, most elements exhibited no concerning levels of heavy metals in chestnut tissue. Most elements were sampled within normal plant tissue ranges with few exceptions. Copper and Se were found to be higher in floral tissue than normal ranges. Manganese was in low concentration in the drip line soils and moderate levels in flower tissue. However, Mn was measured in high concentration in leaves than the recommended values of $500 \mathrm{mg} / \mathrm{kg}$ [65]. Other reclamation studies have reported C. henryi able to hyperaccumulate $\mathrm{Mn}$ in polluted soils; however, that rate of bioaccumulation resulted in tissue concentrations higher than recommended food safety limits $[32,66]$. Conversely, some elements, such as arsenic and cadmium, were not detected at all in leaves or flowers. Studies have shown plants to have physical root barriers, mycorrhizal symbionts, and cellular mechanisms that aid in restricting metal entry into roots $[30,67,68]$. Arsenic is unique and will undergo volatilization (forming gaseous compounds) from leaf surfaces and lost to the atmosphere $[69,70]$. It was also noted that As was significantly lower in drip line soils when compared to the reference soils, which may indicate volatilization by chestnuts without transfer into plant tissue; however, more investigation into root and nut material is required. Further, American chestnut had significantly lower levels of both $\mathrm{As}$ and $\mathrm{Pb}$ in drip line soil when compared to the two hybrid types.

\section{Conclusion}

In summary, after eight years, differences were not detected among tree types regarding metal accumulation in plant tissue, individuals flowering, or ECM colonization. Taller trees were associated with greater ECM root colonization by Cenococcum, Cortinarius, Scleroderma, and Russula, which was correlated with an increase in Al uptake. Overall, soils on this legacy site demonstrated low to average ranges of most metals with no evidence of elements associated with buried spoils translocating from deeper depths to the drip line topsoil after eight growing seasons. Further, some elements such as As, $\mathrm{Cd}$, and $\mathrm{Pb}$ were lower in concentrations in the drip line soils of American chestnut, which may pose questions regarding chestnut's potential to reduce the mobility and bioavailability of some heavy metals in reclaimed soils without bioaccumulating in edible tissues. Also, all trees were producing flowers, which merit further work in the number of viable nuts being produced and concentrations of metals in nut tissue. Hybrids $\mathrm{BC}_{2} \mathrm{~F}_{3}$ may not result in the historical forest tree stature of the pure American, but they may still provide a nut tree, valuable for wildlife and an agroforestry crop for the production of forage feed and human consumption. The more advanced hybrids $\left(\mathrm{BC}_{3}\right)$ are currently being tested and may provide a timber resource more comparable to blight-free American chestnuts [12]. Few elements, such as manganese and aluminum, were in higher concentrations in leaves than flowers, where copper and selenium were significantly higher in floral tissue. Further, significant block effects for selenium and zinc illustrate variability in reclamation soils and require further monitoring throughout other legacy sites that use chestnut as a restoration tree.

\section{Conflicts of Interest}

The authors declare that there are no conflicts of interest regarding the publication of this article.

\section{Acknowledgments}

This work was supported by National Technology and Transfer funds from the US Department of Interior (Office of Surface Mining) and by The Research and Sponsored Program Grant from Western Washington University. The authors thank Julia Chapman, Dr. Keith Gilland, and Sharon Hunter for field and laboratory assistance.

\section{References}

[1] S. L. Anagnostakis, "Chestnut breeding in the United States for disease insect resistance," Plant Disease, vol. 96, no. 10, pp. 13921403, 2012.

[2] E. L. Braun, Deciduous forests of Eastern North America, McGraw-Hill Book Co. Inc., New York, NY, USA, 1950.

[3] J. S. Holms, "Forward in Chestnut and the chestnut blight in North Carolina," NC Geology and Economic Survey Economics, vol. 56, pp. 5-6, 1925.

[4] E. G. Kulman, "The devastation of American Chestnut by blight," in Proceedings of the American Chestnut Symposium, M. L. Double and W. L. MacDonald, Eds., 1978.

[5] M. A. Steele, B. C. McCarthy, and C. H. Keiffer, "Seed dispersal, seed predation, and the American chestnut," The Journal of American Chestnut, vol. 19, pp. 47-54, 2005.

[6] R. H. Lutts, "Like manna from God: The American chestnut trade in southwestern Virginia," Environmental History, vol. 9, no. 3, pp. 497-525, 2004.

[7] S. L. Anagnostakis, "The effect of multiple importations of pests and pathogens on a native tree," Biological Invasions, vol. 3, no. 3, pp. 245-254, 2001.

[8] D. F. Jacobs, H. J. Dalgleish, and C. D. Nelson, "A conceptual framework for restoration of threatened plants: The effective model of American chestnut (Castanea dentata) reintroduction," New Phytologist, vol. 197, no. 2, pp. 378-393, 2013.

[9] C. R. Burnham, "The restoration of the American chestnut," American Scientist, vol. 76, no. 5, pp. 478-487, 1988. 
[10] R. W. McEwan, C. Rhoades, and S. Beiting, "American chestnut (Castanea dentata) in the pre-settlement vegetation of Mammoth Cave National Park, Central Kentucky, USA," Natural Areas Journal, vol. 25, no. 3, pp. 275-281, 2005.

[11] C. Rhoades, D. Loftis, J. Lewis, and S. Clark, "The influence of silvicultural treatments and site conditions on American chestnut (Castanea dentata) seedling establishment in eastern Kentucky, USA," Forest Ecology and Management, vol. 258, no. 7, pp. 1211-1218, 2009.

[12] S. L. Clark, S. E. Schlarbaum, C. C. Pinchot et al., "Reintroduction of American Chestnut in the National Forest System," Journal of Forestry, vol. 112, no. 5, pp. 502-512, 2014.

[13] B. C. McCarthy, J. M. Bauman, and C. H. Keiffer, "Mine land reclamation strategies for the restoration of American chestnut," Ecological Restoration, vol. 26, no. 4, pp. 292-294, 2008.

[14] J. Skousen, T. Cook, L. Wilson-Kokes, and E. Pena-Yewtukhiw, "Survival and growth of chestnut backcross seeds and seedlings on surface mines," Journal of Environmental Quality, vol. 42, no. 3, pp. 690-695, 2013.

[15] K. E. Gilland and B. C. McCarthy, "Reintroduction of american chestnut (Castanea dentata) on reclaimed mine sites in Ohio: Microsite factors controlling establishment success," Northern Journal of Applied Forestry, vol. 29, no. 4, pp. 197-205, 2012.

[16] J. M. Bauman, C. H. Keiffer, and B. C. McCarthy, "Growth performance and chestnut blight incidence (Cryphonectria parasitica) of backcrossed chestnut seedlings in surface mine restoration," New Forests, vol. 45, no. 6, pp. 813-828, 2014.

[17] C. Barton, J. Miller, K. Sena, P. Angel, and M. French, "Evaluating the use of tree shelters for direct seeding of Castanea on a surface mine in Appalachia," Forests, vol. 6, no. 10, pp. 35143527, 2015.

[18] J. A. Franklin, C. E. Zipper, J. A. Burger, J. G. Skousen, and D. F. Jacobs, "Influence of herbaceous ground cover on forest restoration of eastern US coal surface mines," New Forests, vol. 43, no. 5-6, pp. 905-924, 2012.

[19] OSM, "Surface Mining Control and Reclamation Act of 1977," Office of Surface Mining. Soil Science Society of America Journal, vol. 69, pp. 1069-1077, 1993.

[20] J. Skousen and C. E. Zipper, "Post-mining policies and practices in the Eastern USA coal region," International Journal of Coal Science and Technology, vol. 1, no. 2, pp. 135-151, 2014.

[21] W. T. Plass, History of surface mining reclamation and associated legislation. InBarnhisel RI Reclamation of drastically disturbed lands, Agronomy Monograph 41. ASA, SSSA, and CSSA, Madison, Wis, USA, 2nd edition, 2000.

[22] C. E. Zipper, J. A. Burger, J. G. Skousen et al., "Restoring forests and associated ecosystem services on appalachian coal surface mines," Journal of Environmental Management, vol. 47, no. 5, pp. 751-765, 2011.

[23] C. C. Rhoades, S. L. Brosi, A. J. Dattilo, and P. Vincelli, "Effect of soil compaction and moisture on incidence of phytophthora root rot on American chestnut (Castanea dentata) seedlings," Forest Ecology and Management, vol. 184, no. 1-3, pp. 47-54, 2003.

[24] K. M. Dulmer, S. D. LeDuc, and T. R. Horton, "Ectomycorrhizal inoculum potential of northeastern US forest soils for American chestnut restoration: Results from field and laboratory bioassays," Mycorrhiza, vol. 24, no. 1, pp. 65-74, 2014.

[25] J. M. Palmer, D. L. Lindner, and T. J. Volk, "Ectomycorrhizal characterization of an American chestnut ( Castanea dentata )dominated community in Western Wisconsin," Mycorrhiza, vol. 19, no. 1, pp. 27-36, 2008.
[26] M. B. Branzanti, E. Rocca, and A. Pisi, "Effect of ectomycorrhizal fungi on chestnut ink disease," Mycorrhiza, vol. 9, no. 2, pp. 103-109, 1999.

[27] D. H. Marx, W. C. Bryan, and C. E. Cordell, "Survival and growth of pine seedlings with Pisolithus ectomycorrhizae after two years on reforestation sites in North Carolina and Florida," Forest Science, vol. 23, pp. 263-373, 1977.

[28] R. F. Walker, S. B. McLaughlin, and D. C. West, "Establishment of sweet birch on surface mine spoil as influenced by mycorrhizal inoculation and fertility," Restoration Ecology, vol. 12, no. 1, pp. 8-19, 2004.

[29] V. Iordache, F. Gherghel, and E. Kothe, "Assessing the effect of disturbances on ectomycorrhiza diversity," International Journal of Environmental Research and Public Health, vol. 6, no. 2, pp. 414-432, 2009.

[30] J. M. Bauman, C. H. Keiffer, and S. Hiremath, "Facilitation of American chestnut (Castanea dentata) seedling establishment by Pinus virginiana in mine restoration," International Journal of Ecology, Article ID 257326, 2012.

[31] J. M. Bauman, C. H. Keiffer, S. Hiremath, and B. C. Mccarthy, "Soil preparation methods promoting ectomycorrhizal colonization and American chestnut Castanea dentata establishment in coal mine restoration," Journal of Applied Ecology, vol. 50, no. 3, pp. 721-729, 2013.

[32] M. S. Li, Y. P. Luo, and Z. Y. Su, "Heavy metal concentrations in soils and plant accumulation in a restored manganese mineland in Guangxi, South China," Environmental Pollution, vol. 147, no. 1, pp. 168-175, 2007.

[33] J. H. Richards and M. M. Caldwell, "Hydraulic lift: Substantial nocturnal water transport between soil layers by Artemisia tridentata roots," Oecologia, vol. 73, no. 4, pp. 486-489, 1987.

[34] S.-L. Bai, G.-L. Li, Y. Liu, R. K. Dumroese, and R.-H. Lv, "Ostryopsis davidiana seedlings inoculated with ectomycorrhizal fungi facilitate formation of mycorrhizae on Pinus tabulaeformis seedlings," Mycorrhiza, vol. 19, no. 6, pp. 425-434, 2009.

[35] B. C. McCarthy, K. E. Gilland, J. M. Bauman, and C. H. Keiffer, "Factors Affecting Performance of Artificially Regenerated American Chestnut on Reclaimed Mine Sites," Journal American Society of Mining and Reclamation, vol. 2010, no. 1, pp. 582-597, 2010.

[36] R. Botta, G. Vergano, G. Me, and R. Vallania, "Floral biology and embryo development in chestnut (Castanea sativa Mill.)," HortScience, vol. 30, no. 6, pp. 1283-1286, 1995.

[37] T. J. White, T. D. Bruns, S. B. Lee, and J. W. Taylor, Amplification and direct sequencing of fungal ribosomal RNA genes for phylogenetics, PCR Protocols: A Guide to Methods and applications, Academic Press, 1990.

[38] M. Gardes and T. D. Bruns, "ITS primers with enhanced specificity for basidiomycetes-application to the identification of mycorrhizae and rusts," Molecular Ecology, vol. 2, no. 2, pp. 113118, 1993.

[39] S. F. Altschul, T. L. Madden, A. A. Schäffer et al., "Gapped BLAST and PSI-BLAST: a new generation of protein database search programs," Nucleic Acids Research, vol. 25, no. 17, pp. 3389-3402, 1997.

[40] J. Foxcand and S. Weisberg, An $R$ Companion to Applied Regression, Thousand Oaks CA: Sage, 2nd edition, 2011.

[41] C. A. Cox and G. H. Colvin, Evaluation of background metal concentrations in Ohio Soils, Cox - Colvin \&amp; Associates, Inc. Environmental Services, Columbus, Ohio, USA, 1996. 
[42] T. J. Logan and R. H. Miller, "Background levels of Heavy Metals in Ohio Farm Soils," The Ohio State University Ohio Agricultural Research and Development Center, 1983.

[43] P. Schweitzer, 2016, USGS Geochemistry and Minerology. U.S. Department of the Interior. U.S. Geological Survey. http:// mrdata.usgs.gov/ds-801/show-landscape.php?site_id=636.

[44] U.S. EPA Office of Solid Waste and Emergency Response, Hazardous Waste Land Treatment, April 1983.

[45] A. Kabata-Pendias and H. Pendias, Trace elements in soils and plants, CRC Press LLC, 2001.

[46] H. Basar, S. Gürel, and A. V. Katkat, "Metal status of soils and plants irrigated with water from lake Iznnik, Turkey," Communications in Soil Science and Plant Analysis, vol. 40, no. 15-16, pp. 2545-2561, 2009.

[47] T. Vamerali, M. Bandiera, and G. Mosca, "Field crops for phytoremediation of metal-contaminated land. A review," Environmental Chemistry Letters, vol. 8, no. 1, pp. 1-17, 2010.

[48] B. J. Alloway, "Sources of Heavy Metals and Metalloids in Soils," in Heavy Metals in Soils, vol. 22 of Environmental Pollution, Springer, New York, NY, USA, 2013.

[49] E. Gjengedal, T. Martinsen, and E. Steinnes, "Background levels of some major, trace, and rare earth elements in indigenous plant species growing in Norway and the influence of soil acidification, soil parent material, and seasonal variation on these levels," Environmental Modeling \& Assessment, vol. 187, no. 6, article no. 386, 2015.

[50] J. Skousen, J. Gorman, E. Pena-Yewtukhiw et al., "Hardwood tree survival in heavy ground cover on reclaimed land in West Virginia: Mowing and ripping effects," Journal of Environmental Quality, vol. 38, no. 4, pp. 1400-1409, 2009.

[51] D. F. Jacobs, M. F. Selig, and L. R. Severeid, "Aboveground carbon biomass of plantation-grown American chestnut (Castanea dentata) in absence of blight," Forest Ecology and Management, vol. 258, no. 3, pp. 288-294, 2009.

[52] K. E. Gilland, C. H. Keiffer, and B. C. McCarthy, "Seed production of mature forest-grown American chestnut (Castanea dentata (Marsh.) Borkh)," Journal of the Torrey Botanical Society, vol. 139, no. 3, pp. 283-289, 2012.

[53] T. Kogej, A. A. Gorbushina, and N. Gunde-Cimerman, "Hypersaline conditions induce changes in cell-wall melanization and colony structure in a halophilic and a xerophilic black yeast species of the genus Trimmatostroma," Mycological Research, vol. 110, no. 6, pp. 713-724, 2006.

[54] K. E. Clemmensen, A. Bahr, O. Ovaskainen et al., "Roots and associated fungi drive long-term carbon sequestration in boreal forest," Science, vol. 340, no. 6127, pp. 1615-1618, 2013.

[55] E. A. Hobbie and R. Agerer, "Nitrogen isotopes in ectomycorrhizal sporocarps correspond to belowground exploration types," Plant and Soil, vol. 327, no. 1, pp. 71-83, 2010.

[56] E. A. Lilleskov, E. A. Hobbie, and T. R. Horton, "Conservation of ectomycorrhizal fungi: Exploring the linkages between functional and taxonomic responses to anthropogenic $\mathrm{N}$ deposition," Fungal Ecology, vol. 4, no. 2, pp. 174-183, 2011.

[57] S. L. Stephenson, M. B. Ali, A. W. Rollins, M. S. Furches, and K. R. Atherton, "Ectomycorrhizal Fungi Associated with American Chestnut at a Site in Tennessee, USA," Castanea, vol. 82, no. 1, pp. 2-7, 2017.

[58] D. H. Marx, J. I. Ruehle, D. S. Kenney, C. E. Cordell, and J. W. Riffle, "Commercial vegetative inoculum of Pisolithus tinctorius and inoculation techniques for development of ectomycorrhizae on container-grown tree seedlings," Forest Science, vol. 28, pp. 373-400, 1982.
[59] D. A. Perry, H. Margolis, C. Choquette, R. Molina, and J. M. Trappe, "Ectomycorrhizal mediation of competition between coniferous tree species," New Phytologist, vol. 112, pp. 501-511, 1989.

[60] K. Saikkonen, U. Ahonen-Jonnarth, A. M. Markkola et al., "Defoliation and mycorrhizal symbiosis: A functional balance between carbon sources and below-ground sinks," Ecology Letters, vol. 2, no. 1, pp. 19-26, 1999.

[61] R. L. Swaty, R. J. Deckert, T. G. Whitham, and C. A. Gehring, "Ectomycorrhizal abundance and community composition shifts with drought: Predictions from tree rings," Ecology, vol. 85, no. 4, pp. 1072-1084, 2004.

[62] S. Boyce, "Office of Surface Mining (OSM) revegetation team survey results," in Proceedings of the Enhancement of Reforestation at Surface Coal Mines: Technical Interactive Forum, K. Vories and D. Throgmorton, Eds., Southern Illinois Univ, 1999.

[63] G. S. Banuelos, D. B. Vickerman, J. T. Trumble et al., "Biotransfer possibilities of selenium from plants used in phytoremediation," International Journal of Phytoremediation, vol. 4, no. 4, pp. 315329, 2002.

[64] L. P. Gough, H. T. Shacklette, and A. A. Case, Element concentration toxic to plants, animals, and man, U.S. Geological Survey Bulletin 1466, 1979.

[65] Codex Alimentarius Commission (FAO/WHO), "Food additives and Contaminant," Joint FAO/WHO Food standards Programme, ALNORM 01/12A, 2001.

[66] S. H. Wei, Q. X. Zhou, X. Wang, and W. Cao, "Studies on the characteristics of heavy metal hypeaccumulation of weeds in farmlands," China Environmental Science, vol. 1, pp. 105-109, 2004.

[67] K. N. Kalubi, M. Mehes-Smith, and A. Omri, "Comparative analysis of metal translocation in red maple (Acer rubrum) and trembling aspen (Populus tremuloides) populations from stressed ecosystems contaminated with metals," Chemistry and Ecology, vol. 32, no. 4, pp. 312-323, 2016.

[68] S. Tosic, S. Alagic, M. Dimitrijevic, A. Pavlovic, and M. Nujkić, "Plant parts of the apple tree (Malus spp.) as possible indicators of heavy metal pollution," AMBIO, vol. 45 , no. 4, pp. 501-512, 2016.

[69] J. H. Lee, "An overview of phytoremediation as a potentially promising technology for environmental pollution control," Biotechnology and Bioprocess Engineering, vol. 18, no. 3, pp. 431439, 2013.

[70] B. Seshadri, N. S. Bolan, and R. Naidu, "Rhizosphere-induced heavy metal(Loid) transformation in relation to bioavailability and remediation," Soil Science \& Plant Nutrition, vol. 15, no. 2, pp. 524-548, 2015. 


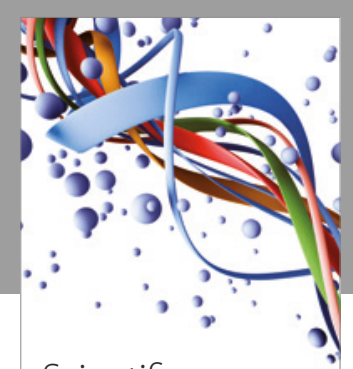

Scientifica
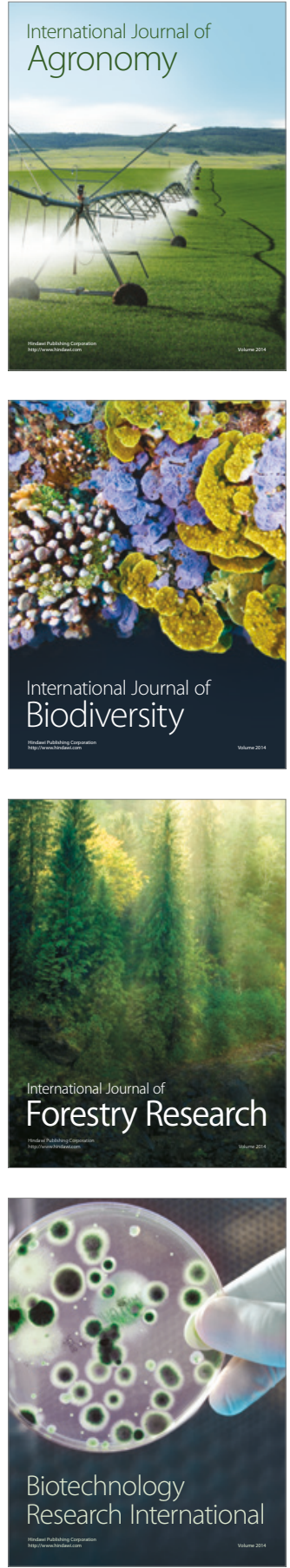
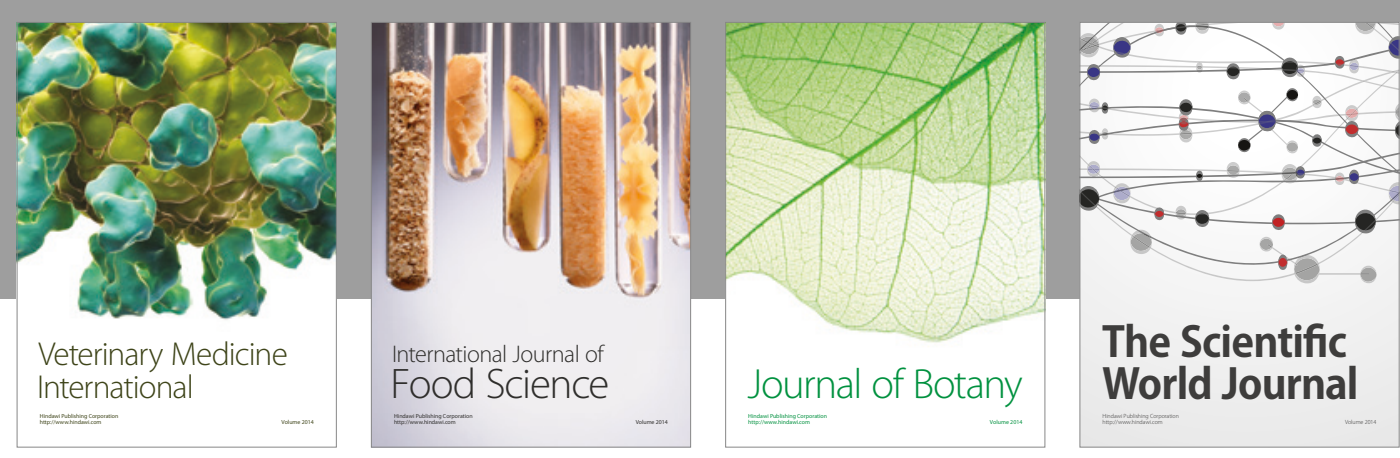

The Scientific

\section{World Journal}

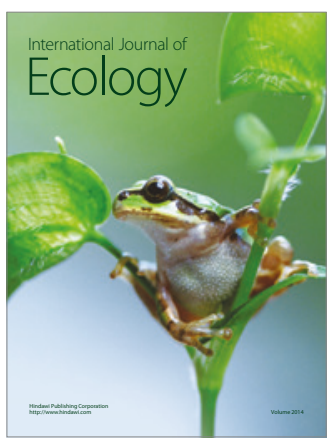

\section{Hindawi}

Submit your manuscripts at

https://www.hindawi.com
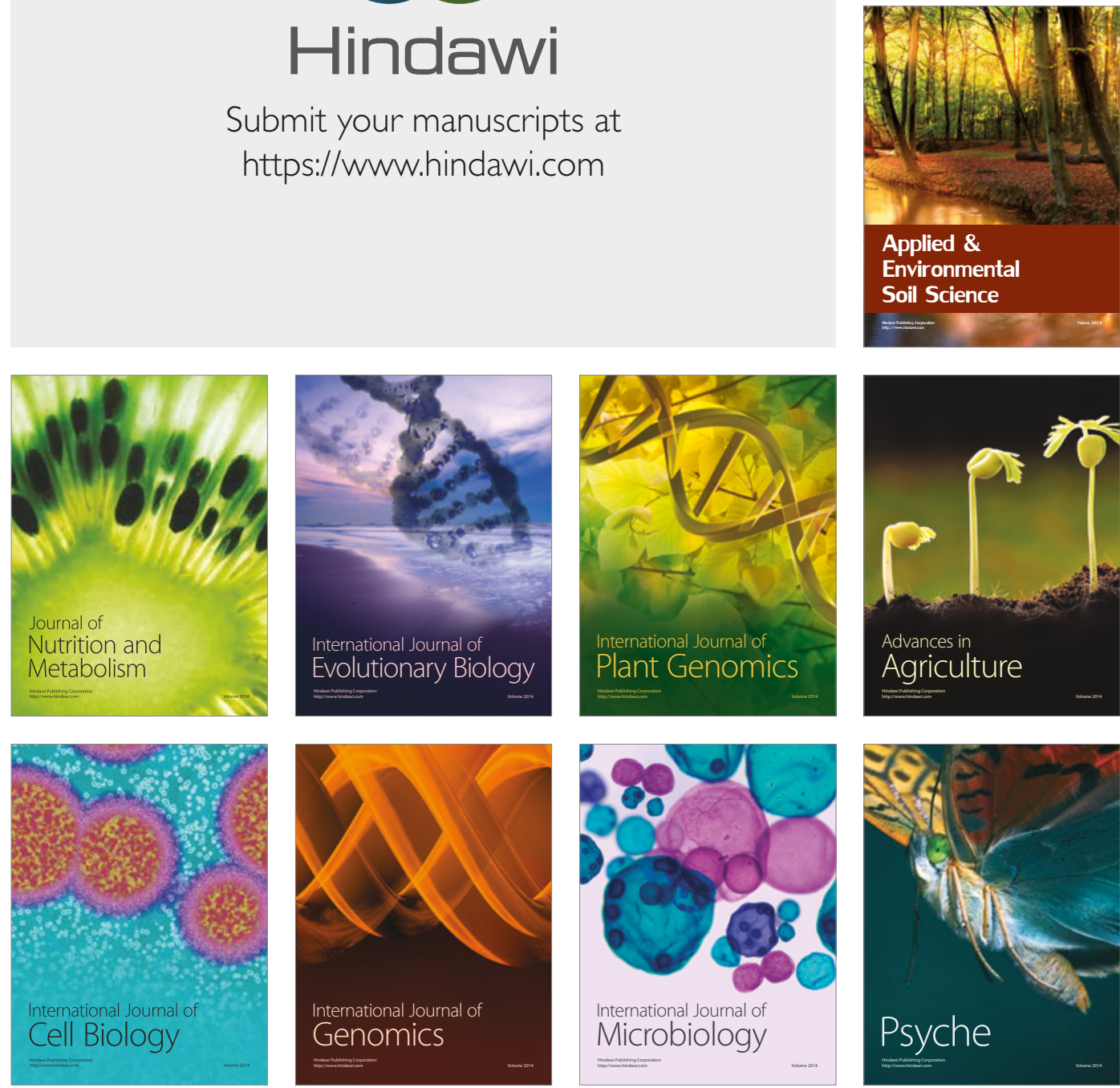

hternational Journal of Microbiology
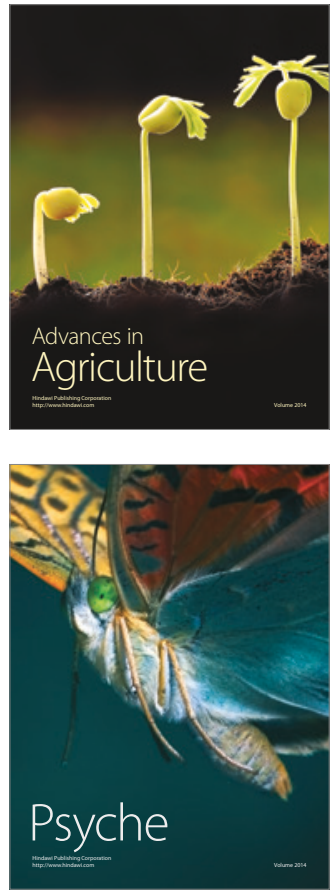